\title{
Rehumaissin typpilannoituksesta ja sadetuksesta
}

\author{
OSMO KARA \\ Valtion maatalouskoneiden tutkimuslaitos, 03450 Olkkala
}

SEPPO PULLI

Maatalouden tutkimuskeskus, Kasvinviljelylaitos, 31600 Jokioinen

\section{Nitrogen fertilization and irrigation of silage maize in Finland}

\author{
Osmo Kara \\ Researcb Institute of Engineering in Agriculture and Forestry, 03450 Olkkala, Finland
}

Seppo Pulli

Agricultural Researcb Centre, Institute of Plant Husbandry 31600 Jokioinen, Finland

Abstract. The influence of $\mathrm{N}$-fertilization and the management technique of fertilizer placement were studied in 1976-78 on the University farm in Siuntio. In 1978 the research program consisted also of irrigationfertilization relationships studies. The main objectives were fertilizer placement prior seeding against fertilizer placement $10 \mathrm{~cm}$ deep on both sides of seeding rows and the requirements of $\mathrm{N}$-fertilization. In the irrigation study the influence of $\mathrm{N}$-fertilization and time of application were studied.

The fertilizer application technique had very little influence on dry matter, raw protein yields and on the raw protein content of silage maize.

The fertilization of $150 \mathrm{~kg} \mathrm{~N} / \mathrm{ha}$ applied on both sides of the seeding rows produced higher yields than the other treatments tested. Higher amounts of nitrogen or splitting the application over a longer period of the growing season did not increase the DM yield of silage maize. However when the $\mathrm{N}$-fertilization was increased from $100 \mathrm{~kg} \mathrm{~N} / \mathrm{ha}$ to $250 \mathrm{~kg} \mathrm{~N} / \mathrm{ha}$ both the raw protein content and the raw protein yield increased.

Irrigation increased silage DM yields significantly. Fertilizer levels $120-170 \mathrm{~kg} \mathrm{~N} / \mathrm{ha}$ produced with and without irrigation in average an equal DM yield to the rate of $240 \mathrm{~kg} \mathrm{~N} / \mathrm{ha}$ applied in one or in several applications. Irrigation increased raw protein yields and lowered the protein concentration of silage maize.

\section{Johdanto}

Maissilla rehukasvina on ollut vähäinen merkitys Suomessa. Kasvin vaateliaisuudesta johtuen se pystyy tuottamaan kunnon satoja vain kaikkein edullisimpina kasvukausina (PULLI ym. 1979). BUNTINGin (1978) mukaan merkittävää maissintuotantoa Ranskassa harjoitetaan $48-50^{\circ} \mathrm{N}$ leveyspiirille Saksassa ja Hollan- 
nissa $54^{\circ} \mathrm{N}$ leveyspiirille ja Tanskassa aina $58^{\circ} \mathrm{N}$ leveyspiirille saakka. Lukuisten tutkimustulosten mukaan kasvualustan maan laadulla on lämpö- ja kosteusoloja vähäisempi vaikutus maissin menestymiseen. BUNTINGin (1978) mukaan tyydyttäviä satoja Pohjois-Euroopassa saadaan kaikilla maalaaduilla $\mathrm{pH}$-alueella 6-8. Suomessa VIRTANEN (1940) on todennut, että maissi menestyy parhaiten kevyehköillä maanlaaduilla, mutta tuottaa hyvin lannoitetuilla savimaillakin huomattavia satoja. Sopivana voidaan pitää samanlaista lannoitusta kuin juurikasveilla. Eläinlanta on erittäin suositeltava maissille.

\section{Kasviravinteiden käyttö}

Tärkein maissin satoon vaikuttava kasviravinne on typpi. Typen puuttuessa lehtiaiheiden kehittyminen hidastuu ja kasvupisteiden solunjakaantuminen alenee. Tämän seurauksena lehtiala, kasvin koko ja kuiva-ainesato vähenevät. PAINin (1978) mukaan riittävä $\mathrm{N}$-lannoitus takaa runsaan lehtialan mahdollisimman aikaisin keväällä ja voimistaa lehtialan kestävyyttä läpi kasvukauden maksimi yhteyttämistehokkuuden kehittämiseksi. Nuoret maissikasvit ottavat typen $\mathrm{NH}_{4}$-muodossa pikemminkin kuin nitraatteina. Kuitenkin myöhemmällä kehitysasteella typenotto tapahtuu $90 \%$ :sti nitraatteina (ARNON 1974). Kasvukauden ensimmäisellä puoliskolla maissiin kerääntyy $76 \%$ N, $61 \% \mathrm{P}$ ja $89 \% \mathrm{~K}$ kasvin kokonaisravinnetarpeesta ja kuiva-ainetta $46 \%$ kokonaiskuiva-ainesadosta (PAIN 1978). HANWAYn (1962) mukaan maissin typenotto on suurimmillaan kukinnan aikana. Fosforia kasvi käyttää runsaimmin kasvun ensimmäisten viikkojen aikana ja fosforin otto lakkaa lähes kokonaan kukinnan jälkeen. Noin $90 \%$ kaliumin kokonaistarpeesta maissi on ottanut kukintavaiheeseen mennessä.

Maissi, kuten muutkin kasvit, ottaa fosforin maasta pääasiassa ortofosfaatteina, mutta myös jonkin verran orgaanisessa muodossa. Fosforin saanti helppoliukoisessa muodossa on erityisen tärkeätä kasvun aikaisessa vaiheessa, koska kehittyvät juuret ovat kykenemättömiä fosforin ottoon maan omista fosforivaroista (ARNON 1974). Fosforin puutoksista johtuvia generatiivisten kasvinosien alkukehityksen häiriintymistä ei voida korjata myöhemmässä vaiheessa fosforilannoituksella.

Kali, typestä ja fosforista poiketen ei ole osana proteiineja tai muita orgaanisia yhdisteitä. Tästä huolimatta maissi käyttää kalia runsaasti. Kalin maissi ottaa maasta $\mathrm{K}^{+}$-ioneina ja käyttää kaikkien tärkeiden fysiologisten prosessien käynnissä pitämiseen. Kali vaikuttaa suoranaisesti kasvin kasvunopeuteen ja sitä tietä sadon määrään (PEASLEC ja MOSS 1966). Tiheä kasvusto yhteyttää alhaisessa valon intensiteetissä huomattavasti tehokkaammin, jos riittävät määrät kalia on saatavilla. Korkeassa valon intensiteetissä valon käyttö kalin vaikutuksesta myös tehostuu liittyen ilmeisesti ilmarakojen tehokkaampaan käyttöön sekä valo- että pimeäolosuhteissa. Kalilla on myös tärkeä merkitys maissin vedenotossa ja jyvän täyttymisessä (LOUE 1963).

\section{Maissin vedenkäyttö}

Säilörehumaissilla, jolla runsas kokonaiskuiva-ainesato on tärkeä satotavoite, mikä tahansa häiriö yhteyttämisessä johtaa alentuneeseen lehtituotantoon ja alentuneeseen satotasoon. CARR ja HOUGHin (1978) mukaan se kasvualustan vesipitoisuus, joka muodostuu kriittiseksi yhteyttämiselle, vaihtelee kasvuasteen, evaporaation 
määrän, maalajin ja juuriston kehitysasteen mukaan. Pohjois-Euroopassa maissin vedenkäytön kannalta kriittinen ajanjakso sattuu ajankohdalle hedekukkien ilmestymisestä 30-40 päivää eteenpäin. Tässä vaiheessa kasvukautta evapotranspiraatio ylittää sademäärän. Suositeltavaa on, että veden määrä juuristokerroksessa ei laske alapuolelle $30 \%$ kasville käyttökelpoisen veden määrästä. Alueilla, joilla evapotranspiraatio on 5-6 mm $\mathrm{H}_{2} \mathrm{O} / \mathrm{pv}$, suositellaan sadetus tehtäväksi silloin, kun kasveille käyttökelpoinen maaveden määrä on vähentynyt tasolle $50 \%$ säilömaissilla ja $40 \%$ jyvämaissilla. Korkeimmat sallitut veden menetykset evapotranspiraation muodossa hienoilla, puolikarheilla ja karheilla maalajeilla ovat CARR ja HOUGHin (1978) mukaan 100-120 mm, 70-80 mm ja 30-40 mm kasvualustoilla, joista juuristo absorboi vettä n. $1 \mathrm{~m}$ kerroksesta. REINHARDTin (1971) mukaan maissi tarvitsee maksimisadon tuottamiseen vegetatiivisen kasvun aikana $50 \mathrm{~mm}$ enemmän sadetta kevyillä maalajeilla kuin tiivisrakenteisilla mailla.

Aineisto ja menetelmät

Kenttäkokeet on tehty Helsingin yliopiston Suitian koetilalla Siuntiossa vuosina 1976-1978.

Lannoituskokeissa käytettiin peruslannoituksena tasaväkevää Y-lannosta (1)15-15). Lannoitemäärät olivat $670 \mathrm{~kg} / \mathrm{ha}$ ja $1000 \mathrm{~kg} / \mathrm{ha}$, jolloin annetun typen määrät olivat 100 ja $150 \mathrm{~kg} / \mathrm{ha}$. Lannoitustapoja oli kaksi, rivilannoittimella poikki koeruutujen ennen kylvöä n. $10 \mathrm{~cm}$ syvyyteen ja kylvön yhteydessä sijoituslannoitus kylvörivin molemmille puolille $\mathrm{n} .10 \mathrm{~cm}$ syvyyteen. Em. peruslannoituksen lisäksi osalle koejäsenistä annettiin kasvukauden aikana pintalannoituksena lisätyppenä $\mathrm{Ou}$ lunsalpietaria $50 \mathrm{~N} \mathrm{~kg} / \mathrm{ha}$ ja $50+50 \mathrm{~N} \mathrm{~kg} / \mathrm{ha}$.

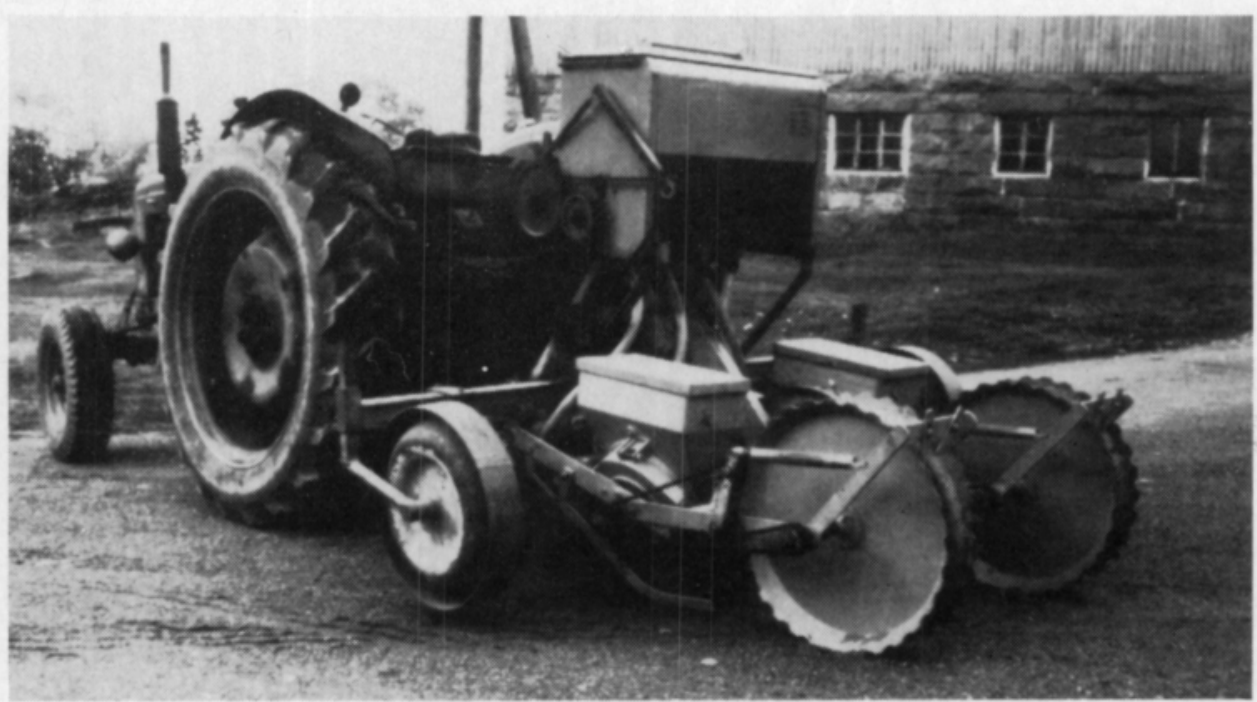

Kuva 1. Maissin kylvökone Kleine Maxicorn, johon on asennettu Vakolassa suunniteltu lannoitusyksikkö. Lannoiteyksikkõ sijoittaa lannoitteen kylvörivin molemmin puolin.

Fig. 1. Cormplanter Kleine Maxicorn fitted with a fertilizer placement attachment designed in Vakola. It places the fertilizer in two rows both sides of the planting furrow. 
Vuonna 1978 lannoitus- ja sadetuskokeessa peruslannoituksena annettiin rivilannoittimella poikki koeruutujen ennen kylvöä ammonoitua Pk-lannosta (2-18-15) $1000 \mathrm{~kg} / \mathrm{ha}$, jolloin annetun typen määrä oli $20 \mathrm{~kg} / \mathrm{ha}$. Kylvön yhteydessä annettiin typpilannoitetta (Oulunsalpietaria) sijoituslannoituksena molemmille puolille kylvöriviä niin, että eri koejäsenten typpitasot olivat tämän jälkeen 20, 120, 170 ja 240 $\mathrm{kg} / \mathrm{ha}$. Osalle koejäsenistä annettiin kasvukauden aikana pintalannoituksena lisätyppeä (Oulunsalpietaria) 120 ja $60+60 \mathrm{~N} \mathrm{~kg} / \mathrm{ha}$.

Kylvö tehtiin kahdella kylvöyksiköllä varustetulla saksalaisella Kleinekylvökoneella, johon oli kylvön yhteydessä tapahtuvaa sijoituslannoitusta varten asennettu Vakolassa suunniteltu lannoitusyksikkö (kuva 1).

Sadetuksena käytettiin Rain Bird-merkkisiä ympyräsadettimia, joiden sadetusympyrän halkaisija oli $\mathrm{n} .10 \mathrm{~m}$. Sadetuskokeessa oli alunperin tarkoituksena tutkia sadetusajankohdan ja sadetuksen määrän vaikutusta. Verrattain runsassateisen ja kylmän loppukesän takia toteutettiin kuitenkin vain aikainen sadetus 6.6. Tämän sadetuksen sai toinen puoli koekentästä ja toinen puoli jäi sadettamatta.

Kuiva-aine määritettiin $2 \times 200 \mathrm{~g}$ silputusta näytteestä kuivaamalla 1 vrk $100^{\circ} \mathrm{C}$. N-määritykset tehtiin Kjehldal-menetelmällä. Raakavalkuaispitoisuudet laskettiin N-pitoisuuksista kertoimella 6.25 .

\begin{tabular}{|c|c|c|c|c|}
\hline & \multicolumn{2}{|c|}{ Lannoituskokeiden suoritus } & \multirow[b]{2}{*}{1978} & \multirow{2}{*}{$\begin{array}{c}\text { Lannoitus- ja } \\
\text { sadetuskoe } \\
1978\end{array}$} \\
\hline & 1976 & 1977 & & \\
\hline Koekaava & Split-plot & Split-plot & Split-plot & Split-plot \\
\hline Kerranteita & 4 & 4 & 4 & 4 \\
\hline Ruutujen koko $\mathrm{m}^{2}$ & 16 & 16 & 16 & 16 \\
\hline Kasvilajike & LG S & LG $s$ & Flash 176 & Flash 176 \\
\hline Kylvōpäivã & 14.5 . & 11.5. & 17.5 . & 18.5 \\
\hline Riviväli cm & 80 & 80 & 80 & 80 \\
\hline Taimietâisyys cm & 12,5 & 12,5 & 12,5 & 12,5 \\
\hline Kylvösyvyys cm & 7 & 7 & 7 & 7 \\
\hline Sadetusajankohta $(30 \mathrm{~mm})$ & & & & 6.6. \\
\hline \multicolumn{5}{|l|}{ Lisätyppilannoituksen } \\
\hline ajankohdat & 14.6. ja 9.8 . & 20.7. ja 16.8 . & 5.7. ja 28.7. & 15.7. ja 28.7. \\
\hline Sadonkorjuun ajankohta & 10.10 & 25.9. & 24.9. & 26.9. \\
\hline
\end{tabular}

Lannoitustason ja -tavan vaikutus sadon määrään

Lannoitustavan, lannoitusmäärien sekä lisälannoituksen vaikutus säilörehumaissin tuoresatoihin, kuiva-ainesatoihin ja sadon kypsyysasteeseen ilmaistuna kuivaaineprosenttina esitetään taulukoissa $\mathbf{l}-3$. Sijoituslannoituksella saatiin keskimäärin $3 \%$ suuremmat kuiva-ainesadot kuin rivilannoituksella (taulukko 2). Satoero ei ole tilastollisesti merkittävä.

Typpilannoituksella on lyhyestä kasvukaudestamme johtuen ollut varsin vähäinen vaikutus käsittelyeroihin. Suurimmalla peruslannoitustasolla kylvön yhteydessä annettu typpilannoitus $150 \mathrm{~kg} \mathrm{~N} / \mathrm{ha}$ on antanut suurimmat tuore- ja kuiva-ainesadot (taulukot 1, 2). Lisätypet samalla peruslannoitustasolla eivät ole lisänneet sadon määrää. Pienemmällä peruslannoitustasolla $100 \mathrm{~kg} \mathrm{~N} / \mathrm{ha}$ kaksi kertaa annettu lisätyppi $50 \mathrm{~kg} \mathrm{~N} / \mathrm{ha}$ on lisännyt kuiva-ainesatoa $6 \%$-yksikköä. Mitkään satoerot sekä 
Taulukko 1. Lannoituskokeen tuoresadot 1976-1978

Table 1. Fresb matter yields of fertilization trials $1976-1978$

\begin{tabular}{|c|c|c|c|c|c|}
\hline \multirow{2}{*}{$\begin{array}{l}\text { Peruslannoitus } \\
\text { Basic fertilization }\end{array}$} & \multirow{2}{*}{$\begin{array}{l}\mathrm{N} \\
\mathrm{kg} / \mathrm{ha}\end{array}$} & \multicolumn{3}{|c|}{ Tuoresadotm Frescb yields ( $\mathrm{t} / \mathrm{ha}$ ) } & \multirow{2}{*}{$\begin{array}{l}\text { Keskim. } \\
\text { Avg. }\end{array}$} \\
\hline & & 1976 & 1977 & 1978 & \\
\hline Rivilannoitus & 100 & 31.8 & 34.1 & 38.4 & 34.7 \\
\hline Placement prior & $100+50$ & 34.2 & 34.7 & 37.2 & 35.3 \\
\hline \multirow[t]{5}{*}{ seeding } & $100+50+50$ & 35.0 & 37.3 & 40.8 & 37.7 \\
\hline & 150 & 36.1 & 36.9 & 39.0 & 37.4 \\
\hline & $150+50$ & 34.1 & 36.5 & 35.4 & 35.4 \\
\hline & $150+50+50$ & 35.1 & 39.1 & 31.9 & 35.4 \\
\hline & $\begin{array}{l}\text { Keskim. } \\
\text { Avg. }\end{array}$ & 34.4 & 36.4 & 37.2 & $36.0 \mathrm{~A}$ \\
\hline Sijoituslannoitus & 100 & 30.4 & 39.4 & 35.5 & 35.1 \\
\hline Placement on the & $100+50$ & 33.5 & 36.9 & 35.1 & 35.1 \\
\hline botb sides of & $100+50+50$ & 32.1 & 39.5 & 39.3 & 37.0 \\
\hline \multirow[t]{12}{*}{ seeding rows } & 150 & 33.0 & 40.2 & 40.7 & 38.0 \\
\hline & $150+50$ & 34.5 & 34.6 & 38.5 & 35.9 \\
\hline & $150+50+50$ & 35.5 & 38.1 & 37.8 & 37.1 \\
\hline & $\begin{array}{l}\text { Keskim. } \\
\text { Avg. }\end{array}$ & 33.2 & 38.1 & 37.8 & $36.4 \mathrm{~A}$ \\
\hline & \multicolumn{5}{|c|}{$\begin{array}{l}\text { Lannoitus keskimäärin } \\
\text { Effect of fertilization avg. }\end{array}$} \\
\hline & 100 & 31.1 & 36.8 & 36.8 & $34.9 \mathrm{a}$ \\
\hline & $100+50$ & 33.9 & 35.8 & 36.2 & $35.2 \mathrm{a}$ \\
\hline & $100+50+50$ & 33.6 & 38.4 & 40.1 & $37.4 \mathrm{a}$ \\
\hline & 150 & 34.6 & 38.6 & 39.9 & $37.7 \mathrm{a}$ \\
\hline & $150+50$ & 34.3 & 35.6 & 37.0 & $35.7 \mathrm{a}$ \\
\hline & $150+50+50$ & 35.3 & 38.6 & 34.9 & $36.3 \mathrm{a}$ \\
\hline & $\begin{array}{l}\text { Keskim. } \\
\text { Avg. }\end{array}$ & $33.8 \mathrm{~A}$ & $37.3 \mathrm{~A}$ & $37.5 \mathrm{~A}$ & 36.2 \\
\hline
\end{tabular}

PME.0S (LSD)

Vuodet NS (Years)

Lannoitustavat NS (Application forms)

Lannoitusmäärät NS (Application rates)

tuoresadoissa että kuiva-ainesadoissa eivät ole tilastollisesti merkittäviä. Lannoitustavalla ja käytetyillä typen määrillä on ollut vain vähäinen vaikutus maissin kehitysasteen hidastumiseen tai jouduttamiseen. Kasvuston kuiva-aineprosentti eroaa erittäin vähän eri lannoitustasoilla (taulukko 3 ) ja on vain $0.3 \%$-yksikköä suurempi sijoituslannoitusta käytettäessä kuin rivilannoittaen.

Edellä esitetyt, maissin kasvulle suhteellisen epäedullisen kolmen kasvukauden tulokset osoittavat, että typpilannoitemäärät $100-150 \mathrm{~kg} \mathrm{~N} / \mathrm{ha}$ annettuna keväällä kylvön yhteydessä ovat kasvun kannalta riittäviä ja kehityksen kannalta ehkä ylimitoitettuja. Suitiassa saadut tulokset ovat samansuuntaisia useissa eri maissa saatujen lannoitustulosten kanssa. Yhdysvalloissa ja Euroopassa typpilannoituksella on saatu sadonlisäystä aina $200 \mathrm{~kg} \mathrm{~N} / \mathrm{ha}$ saakka (KROTH ja COLYER 1967, DOSS ym. 
Taulukko 2. Lannoituskokeen kuiva-ainesadot 1976-1978

Table 2. Dry matter yields of fertilization trials 1976-1978

\begin{tabular}{|c|c|c|c|c|c|}
\hline \multirow{3}{*}{$\begin{array}{l}\text { Peruslannoitus } \\
\text { Basic fertilization }\end{array}$} & \multicolumn{5}{|c|}{ Kuiva-ainesadot } \\
\hline & \multirow[b]{2}{*}{$\mathrm{kg} / \mathrm{ha}$} & \multicolumn{3}{|c|}{ Dry matter yields $(\mathrm{kg} / \mathrm{ha})$} & \multirow{2}{*}{$\begin{array}{l}\text { Keskim. } \\
\text { Avg. }\end{array}$} \\
\hline & & 1976 & 1977 & 1978 & \\
\hline Rivilannoitus & 100 & $5009 a$ & $5203 \mathrm{ab}$ & $6332 c$ & 5515 a \\
\hline Placement prior & $100+50$ & $5101 \mathrm{a}$ & $5003 \mathrm{a}$ & 6039 bc & $5381 \mathrm{a}$ \\
\hline \multirow[t]{5}{*}{ seeding } & $100+50+50$ & $5708 a$ & $5334 \mathrm{ab}$ & $6345 c$ & $5796 a$ \\
\hline & 150 & $5613 a$ & $5815 \mathrm{ab}$ & $6047 \mathrm{bc}$ & 4825 a \\
\hline & $150+50$ & 5451 a & $5230 \mathrm{ab}$ & $5223 \mathrm{ab}$ & $5301 \mathrm{a}$ \\
\hline & $150+50+50$ & $5746 \mathrm{a}$ & $6149 b$ & 4770 a & 5561 a \\
\hline & $\begin{array}{l}\text { Keskim. } \\
\text { Avg. }\end{array}$ & $5441 \mathrm{~A}$ & $5455 \mathrm{~A}$ & $5793 \mathrm{~A}$ & $5563 \mathrm{~A}$ \\
\hline Sijoituslannoitus & 100 & 4968 a & $5644 a$ & $5725 \mathrm{a}$ & $5446 a$ \\
\hline Placement on the & $100+50$ & $5518 a$ & 5699 a & $5513 a$ & 5577 a \\
\hline botb sides of & $100+50+50$ & $5432 \mathrm{a}$ & $5873 a$ & $6222 \mathrm{a}$ & $5842 a$ \\
\hline \multirow{4}{*}{ seeding rows } & 150 & $5428 \mathrm{a}$ & $6007 \mathrm{a}$ & 6672 a & $6036 a$ \\
\hline & $150+50$ & $5562 a$ & $5100 \mathrm{a}$ & $5968 \mathrm{a}$ & $5543 a$ \\
\hline & $150+50+50$ & $5934 a$ & $6070 a$ & $5686 a$ & $5897 a$ \\
\hline & $\begin{array}{l}\text { Keskim. } \\
\text { Avg. }\end{array}$ & $5474 \mathrm{~A}$ & $5733 \mathrm{~A}$ & $5965 \mathrm{~A}$ & $5724 \mathrm{~A}$ \\
\hline \multirow{9}{*}{ Effect of fertilizat } & \multicolumn{5}{|c|}{ Lannoitus keskimäärin } \\
\hline & & & & & \\
\hline & 100 & 4989 a & $5424 \mathrm{ab}$ & $6029 \mathrm{~b}$ & 5481 a \\
\hline & $100+50$ & $5310 \mathrm{ab}$ & $5351 \mathrm{ab}$ & $5776 \mathrm{ab}$ & $5479 a$ \\
\hline & $100+50+50$ & $5570 \mathrm{ab}$ & $5604 \mathrm{ab}$ & $6284 \mathrm{~b}$ & $5819 a$ \\
\hline & 150 & $5521 \mathrm{ab}$ & $5911 \mathrm{ab}$ & $6360 \mathrm{~b}$ & 5931 a \\
\hline & $150+50$ & $5507 \mathrm{ab}$ & $5165 \mathrm{a}$ & $5596 \mathrm{ab}$ & $5422 \mathrm{a}$ \\
\hline & $150+50+50$ & $5840 \mathrm{~b}$ & $6110 \mathrm{~b}$ & $5228 \mathrm{a}$ & $5729 a$ \\
\hline & $\begin{array}{l}\text { Keskim. } \\
\text { Avg. }\end{array}$ & $5458 \mathrm{~A}$ & $5594 \mathrm{~A}$ & $5879 \mathrm{~A}$ & $5644 \mathrm{~A}$ \\
\hline
\end{tabular}

PME.0S (LSD)

Vuodet NS (Years)

Lannoitustavat NS (Application forms)

Lannoitusmäärät NS (Application rates)

1967. CUMMINS 1972, ALLEN ym. 1974). LABER (1976) Itävallassa suosittelee säilörehumaissille lannoitusmääriä $150-200 \mathrm{~kg} \mathrm{~N} / \mathrm{ha}, 100-150 \mathrm{~kg} \mathrm{P} \mathrm{O}_{2} \mathrm{O} / \mathrm{ha}$ ja $200-280 \mathrm{~kg} \mathrm{~K} \mathrm{~K}_{2} \mathrm{O} / \mathrm{ha}$. Italiassa LANZAn (1961) suositukset ovat $160-200 \mathrm{~kg}$ $\mathrm{N} / \mathrm{ha} 45-50 \mathrm{~kg} \mathrm{P} / \mathrm{ha}$ ja $80-100 \mathrm{~kg} \mathrm{~K} / \mathrm{ha}$. Kanadassa WHITE (1978) on 3vuotisten kokeiden perusteella suositellut eri osiin maata seuraavia ravinnemääriä: $\mathrm{N}=70-190 \mathrm{~kg} / \mathrm{ha}, \mathrm{P}=10-75 \mathrm{~kg} / \mathrm{ha}$ ja $\mathrm{K}=30-140 \mathrm{~kg} / \mathrm{ha}$ maan viljavuudesta ja sadon käyttömuodosta riippuen. Kanadalaisissa kokeissa on ilman typpeä saatu $75 \%$ maksimisadosta ja typpitasolla $90 \mathrm{~kg} \mathrm{~N} / \mathrm{ha} 95 \%$ maksimisadosta. Suitiassa saadut tulokset ovat samansuuntaisia myös Tanskassa nousevien typpimäärien kokeista tehtyjen havaintojen kanssa, joiden mukaan $\mathrm{N}$-lannoitustaso $125-150 \mathrm{~kg} / \mathrm{ha}$ on todettu edullisimmaksi (HØJMARK 1977). 
Taulukko 3. Satojen kuiva-ainepitoisuudet lannoituskokeissa 1976-1978

Table 3. Dry matter contents of yields in fertilization trials 1976-1978

\begin{tabular}{|c|c|c|c|c|c|}
\hline \multirow[t]{2}{*}{$\begin{array}{l}\text { Peruslannoitus } \\
\text { Basic fertilization }\end{array}$} & \multirow{2}{*}{$\begin{array}{l}\mathrm{N} \\
\mathrm{kg} / \mathrm{ha}\end{array}$} & \multicolumn{3}{|c|}{$\begin{array}{l}\text { Kuiva-ainepitoisuudet } \\
\text { Dry matter contents (\%) }\end{array}$} & \multirow{2}{*}{$\begin{array}{l}\text { Keskim } \\
\text { Avg. }\end{array}$} \\
\hline & & 1976 & 1977 & 1978 & \\
\hline Rivilannoitus & 100 & $15.7 \mathrm{a}$ & $15.2 \mathrm{a}$ & $16.5 \mathrm{~b}$ & $15.8 \mathrm{a}$ \\
\hline Placement prior & $100+50$ & $14.9 \mathrm{a}$ & $14.4 \mathrm{a}$ & $16.1 \mathrm{ab}$ & $15.1 \mathrm{a}$ \\
\hline \multirow[t]{5}{*}{ seeding } & $100+50+50$ & $16.4 \mathrm{a}$ & $14.3 \mathrm{a}$ & $15.5 \mathrm{ab}$ & $15.4 \mathrm{a}$ \\
\hline & 150 & $15.5 \mathrm{a}$ & $15.8 \mathrm{a}$ & $15.5 \mathrm{ab}$ & $15.6 \mathrm{a}$ \\
\hline & $150+50$ & $16.1 \mathrm{a}$ & $14.4 \mathrm{a}$ & $14.7 \mathrm{a}$ & $15.1 \mathrm{a}$ \\
\hline & $150+50+50$ & $16.4 \mathrm{a}$ & $15.7 \mathrm{a}$ & $15.0 \mathrm{ab}$ & $15.7 \mathrm{a}$ \\
\hline & $\begin{array}{l}\text { Keskim. } \\
\text { Avg. }\end{array}$ & $15.8 \mathrm{~A}$ & $15.0 \mathrm{~A}$ & $15.6 \mathrm{~A}$ & $15.5 \mathrm{~A}$ \\
\hline Sijoituslannoitus & 100 & $16.4 \mathrm{a}$ & $14.3 \mathrm{a}$ & 16.1 a & $15.6 \mathrm{a}$ \\
\hline Placement on tbe & $100+50$ & $16.5 \mathrm{a}$ & $15.4 \mathrm{ab}$ & $15.7 \mathrm{a}$ & $15.9 \mathrm{a}$ \\
\hline botb sides of & $100+50+50$ & $16.8 \mathrm{a}$ & $14.9 \mathrm{ab}$ & $15.9 \mathrm{a}$ & $15.9 \mathrm{a}$ \\
\hline \multirow[t]{12}{*}{ seeding rows } & 150 & $16.5 \mathrm{a}$ & $15.0 \mathrm{ab}$ & $16.4 \mathrm{a}$ & $16.0 \mathrm{a}$ \\
\hline & $150+50$ & $16.2 \mathrm{a}$ & $14.8 \mathrm{ab}$ & $15.5 \mathrm{a}$ & $15.5 \mathrm{a}$ \\
\hline & $150+50+50$ & $16.7 \mathrm{a}$ & $16.0 \mathrm{~b}$ & $15.1 \mathrm{a}$ & $15.9 \mathrm{a}$ \\
\hline & $\begin{array}{l}\text { Keskim. } \\
\text { Avg. }\end{array}$ & $16.5 \mathrm{~A}$ & $15.1 \mathrm{~A}$ & $15.8 \mathrm{~A}$ & $15.8 \mathrm{~A}$ \\
\hline & \multicolumn{5}{|c|}{$\begin{array}{l}\text { Lannoitus keskimäärin } \\
\text { Effect of fertilization avg. }\end{array}$} \\
\hline & 100 & $16.1 \mathrm{a}$ & $14.8 \mathrm{a}$ & $16.3 \mathrm{~b}$ & $15.7 \mathrm{a}$ \\
\hline & $100+50$ & $15.7 \mathrm{a}$ & $14.9 \mathrm{a}$ & $15.9 \mathrm{ab}$ & $15.5 \mathrm{a}$ \\
\hline & $100+50+50$ & $16.6 \mathrm{a}$ & $14.7 \mathrm{a}$ & $15.7 \mathrm{ab}$ & $15.7 \mathrm{a}$ \\
\hline & 150 & $16.0 \mathrm{a}$ & $15.4 \mathrm{a}$ & $16.0 \mathrm{ab}$ & $15.8 \mathrm{a}$ \\
\hline & $150+50$ & $16.2 \mathrm{a}$ & $14.6 \mathrm{a}$ & $15.1 \mathrm{a}$ & $15.3 \mathrm{a}$ \\
\hline & $150+50+50$ & $16.6 \mathrm{a}$ & $15.9 \mathrm{a}$ & $15.1 \mathrm{a}$ & $15.8 \mathrm{a}$ \\
\hline & $\begin{array}{l}\text { Keskim. } \\
\text { Avg. }\end{array}$ & $16.2 \mathrm{~B}$ & $15.1 \mathrm{~A}$ & $15.7 \mathrm{~B}$ & $15.7 \mathrm{~A}$ \\
\hline
\end{tabular}

PME.05 (LSD)

Vuodet 0.4 (Years)

Lannoitustavat NS (Application forms)

Lannoitusmäärät NS (Application rates)

Lannoitustason ja -tavan vaikutus raakavalkuaissatoon ja -pitoisuuteen

Rivilannoituksella tai sijoituslannoituksella saatu säilömaissin valkuaispitoisuus tai pinta-alayksiköltä korjattu valkuaissato eivät eronneet merkittävästi toisistaan (taulukot 4, 5). Typpilannoituksen lisäys nosti valkuaissatoja rivilannoitettaessa vain viileänä kesänä 1977, mutta sijoituslannoituksella kahtena kasvukautena ja keskimäärin kolmena kasvukautena. Tulosta voidaan tulkita siten, että rivilannoitettaessa ravinteet saattavat olla paremmin kasvin käytettävissä, jolloin voidaan tyytyä alhaisempaan $\mathrm{N}$-tasoon. Valkuaispitoisuuden muutokset vastaavat HEILin (1975) Saksassa ja HØJMARKin (1977) Tanskassa kokemuksia säilörehumaissilla, jolloin yli $100 \mathrm{~kg} \mathrm{~N} / \mathrm{ha}$ typpilannoituksella saatiin varsin vähäisiä typpipitoisuuden lisäyksiä. 
Taulukko 4. Lannoituskokeen valkuaissadot 1976-1978

Table 4. Protein yields of fertilization trials 1976-1978

\begin{tabular}{|c|c|c|c|c|c|}
\hline \multirow[t]{2}{*}{$\begin{array}{l}\text { Peruslannoitus } \\
\text { Basic fertilization }\end{array}$} & \multirow{2}{*}{$\begin{array}{l}\mathrm{N} \\
\mathrm{kg} / \mathrm{ha}\end{array}$} & \multicolumn{2}{|c|}{$\begin{array}{l}\text { Valkuaissadot } \\
\text { Protein yields }(\mathrm{kg} / \mathrm{ha})\end{array}$} & \multirow[b]{2}{*}{1978} & \multirow{2}{*}{$\begin{array}{l}\text { Keskim. } \\
\text { Avg. }\end{array}$} \\
\hline & & 1976 & 1977 & & \\
\hline Rivilannoitus & 100 & $536 a$ & $572 a$ & $418 a$ & $509 a$ \\
\hline Placement prior & $100+50$ & $597 a$ & $535 \mathrm{a}$ & 447 a & $526 a$ \\
\hline \multirow[t]{5}{*}{ seeding } & $100+50+50$ & $651 \mathrm{a}$ & $603 \mathrm{ab}$ & $533 a$ & $596 a$ \\
\hline & 150 & $516 a$ & $669 \mathrm{ab}$ & $508 \mathrm{a}$ & $564 a$ \\
\hline & $150+50$ & $621 \mathrm{a}$ & $606 \mathrm{ab}$ & $476 \mathrm{a}$ & $568 \mathrm{a}$ \\
\hline & $150+50+50$ & $628 \mathrm{a}$ & $769 \mathrm{~b}$ & 444 a & $614 a$ \\
\hline & $\begin{array}{l}\text { Keskim. } \\
\text { Avg. }\end{array}$ & $592 \mathrm{~A}$ & $626 \mathrm{~A}$ & $471 \mathrm{~A}$ & $563 \mathrm{~A}$ \\
\hline Sijoituslannoitus & 100 & $542 \mathrm{a}$ & $559 a$ & $361 \mathrm{a}$ & $487 \mathrm{a}$ \\
\hline Placement on the & $100+50$ & $629 a$ & $624 \mathrm{ab}$ & $369 \mathrm{a}$ & $541 \mathrm{ab}$ \\
\hline botb sides of & $100+50+50$ & $614 a$ & $682 \mathrm{ab}$ & $523 \mathrm{ab}$ & $606 \mathrm{bc}$ \\
\hline \multirow[t]{12}{*}{ seeding rows } & 150 & $603 a$ & $613 \mathrm{ab}$ & $434 \mathrm{ab}$ & $550 \mathrm{ab}$ \\
\hline & $150+50$ & $640 \mathrm{a}$ & $530 \mathrm{a}$ & $501 \mathrm{ab}$ & $557 \mathrm{ab}$ \\
\hline & $150+50+50$ & $653 a$ & $753 \mathrm{~b}$ & $597 \mathrm{~b}$ & $668 c$ \\
\hline & $\begin{array}{l}\text { Keskim. } \\
\text { Avg. }\end{array}$ & $614 \mathrm{~A}$ & $627 \mathrm{~A}$ & $464 \mathrm{~A}$ & $568 \mathrm{~A}$ \\
\hline & \multicolumn{5}{|c|}{$\begin{array}{l}\text { Lannoitus keskimäärin } \\
\text { Effect of fertilization avg. }\end{array}$} \\
\hline & 100 & $539 \mathrm{a}$ & $566 a$ & 390 a & 498 a \\
\hline & $100+50$ & $613 \mathrm{ab}$ & $580 \mathrm{a}$ & 408 a & $536 \mathrm{ab}$ \\
\hline & $100+50+50$ & $633 \mathrm{~b}$ & $643 a$ & $528 \mathrm{~b}$ & $601 \mathrm{bc}$ \\
\hline & 150 & $560 \mathrm{ab}$ & 641 a & $471 \mathrm{ab}$ & $557 \mathrm{ab}$ \\
\hline & $150+50$ & $631 \mathrm{~b}$ & 568 a & $489 \mathrm{~b}$ & $563 \mathrm{ab}$ \\
\hline & $150+50+50$ & $641 \mathrm{~b}$ & $761 \mathrm{~b}$ & $521 \mathrm{~b}$ & $641 c$ \\
\hline & $\begin{array}{l}\text { Keskim. } \\
\text { Avg. }\end{array}$ & $603 \mathrm{~A}$ & $627 \mathrm{~A}$ & $468 \mathrm{~B}$ & 566 \\
\hline
\end{tabular}

PME.05 (LSD)

Vuodet 41 (Years)

Lannoitustavat NS (Application forms)

Lannoitusmäärät 43 (Application rates)

Yhdysvalloissa FLYNN ym. (1975) havaitsivat vähäistä valkuaispitoisuuden nousua varressa ja lehdissä nostettaessa N-tasoa $120 \quad 240$ kg N/ha. Jyvissä valkuaispitoisuuden nousu oli vielä vähäisempää.

\section{Maissin sadetus ja lannoitus}

Sadetus- ja lannoituskokeen tulokset edustavat kasvukautta 1978 ja ovat näin ollen vain suuntaa antavia. Sadetus (taulukko 6) on lisännyt maissin kuiva-ainesatoa $16.8 \%$ sadettamattomaan verrattuna. Ilman sadetusta suurimmat kuiva-ainesadot tuotettiin typpimäärällä $170 \mathrm{~kg} \mathrm{~N} / \mathrm{ha}$. Sadetettaessa kuiva-ainesadot eivät sadetta- 


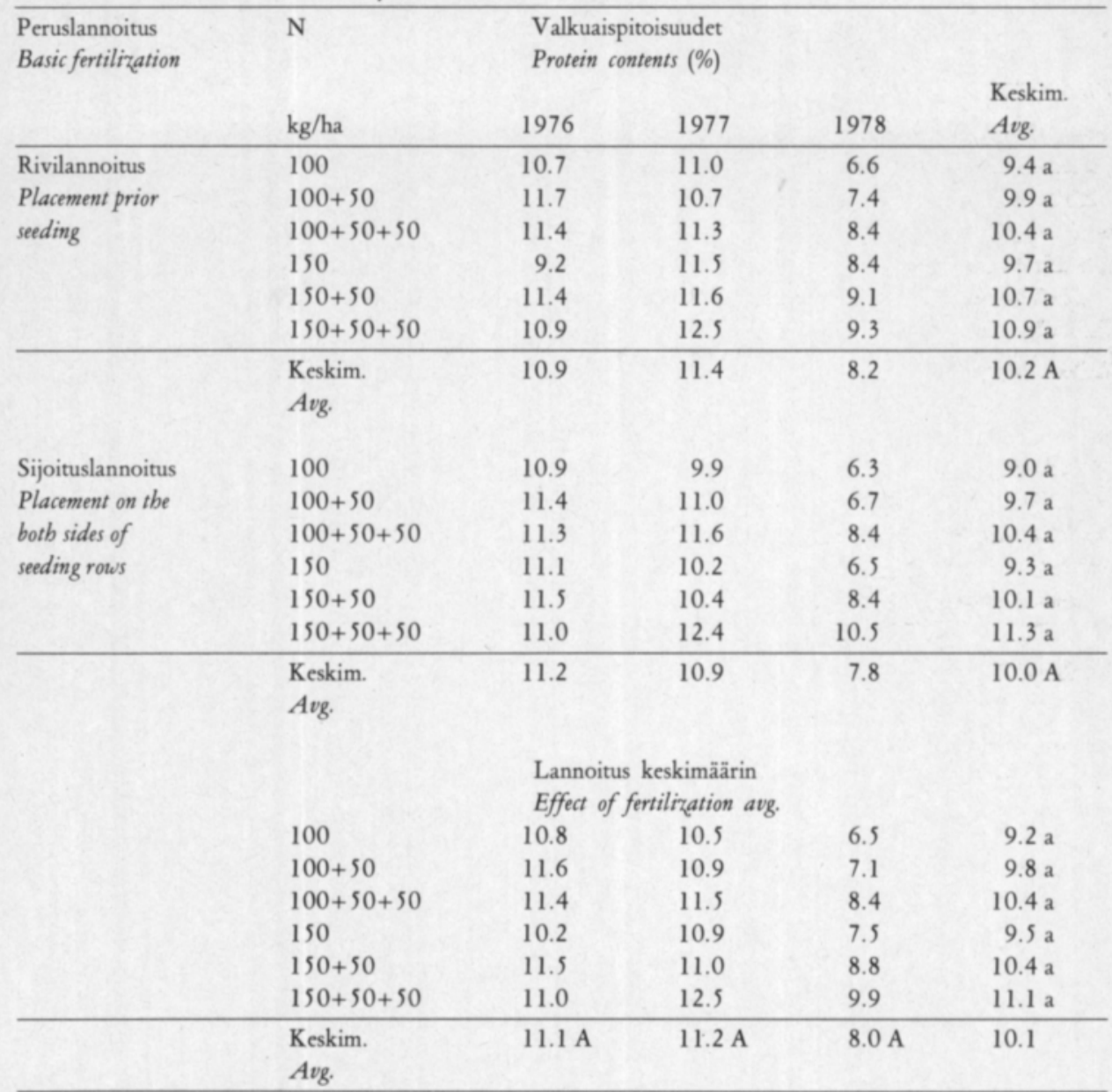

PME.05 (LDS)

Vuodet NS (Years)

Lannoitustavat NS (Application forms)

Lannoitusmäärät NS (Application rates)

mattomasta kasvustosta poiketen alentuneet suuremmilla $\mathrm{N}$-määrillä. Erilaisista kasvuolosuhteista johtuen tulokset eroavat merkittävästi FLYNNin ym. (1957) Yhdysvalloissa havaitsemasta trendistä, jolloin $120 \mathrm{~kg} \mathrm{~N} / \mathrm{ha}$ typpitasolla saatiin sadetetusta kasvustosta 4-kertainen sato verrattuna sadettamattomaan ja korkeammalla N-tasolla $240 \mathrm{~kg} \mathrm{~N} / \mathrm{ha}$ 3-kertainen sato verrattuna sadettamattomaan kasvustoon.

Raakavalkuaissadon huippu saavutettiin typpilannoituksella $170 \mathrm{~kg} \mathrm{~N} / \mathrm{ha}$. Sama trendi havaittiin sekä sadetetuilla että sadettamattomilla ruuduilla (taulukko 6). Typen hyväksikäyttö sadetetuilla ruuduilla oli sadettamatonta parempi, jota osoittaa satojen valkuaispitoisuus, mikä sadettamattomalla ruudulla saavutti suurimman arvonsa lannoitustasolla $170 \mathrm{~kg} \mathrm{~N} / \mathrm{ha}$. Valkuaissatojen ja valkuaispitoisuuksien suhteet ovat samanlaiset kuin FLYNNillä ym. (1957) Yhdysvalloissa. 
Taulukko 6. Lannoitus- ja sadetuskokeiden satotuloksia 1978

Table 6. Yields of fertilization and irrigation trials 1978

\begin{tabular}{|c|c|c|c|c|c|c|}
\hline \multirow{3}{*}{$\begin{array}{l}\text { Sadetus } \\
\text { Irrigation }\end{array}$} & \multirow{3}{*}{$\begin{array}{l}\text { Lannoitus } \\
\text { Fertilizat- } \\
\text { ion } \\
\mathrm{N} / \mathrm{kg} / \mathrm{ha}\end{array}$} & \multicolumn{3}{|c|}{ Sadot, Yields (t/ha) } & \multicolumn{2}{|c|}{ Pitoisuudet, Contents (\%) } \\
\hline & & Tuoresato & $\begin{array}{l}\text { Kuiva- } \\
\text { ainesato }\end{array}$ & $\begin{array}{l}\text { Valkuais- } \\
\text { sato } \\
\text { Protein }\end{array}$ & $\begin{array}{l}\text { Kuiva- } \\
\text { aine }\end{array}$ & Valkuainen \\
\hline & & Frescob wit. & Dry matter & Protetn & Dry matter & Protem \\
\hline Sadettamaton & 20 & $19.0 \mathrm{a}$ & $2.56 \mathrm{a}$ & $0.228 \mathrm{a}$ & 13.5 a & 8.9 \\
\hline Not irri- & 120 & $29.9 \mathrm{~b}$ & $4.27 \mathrm{~b}$ & $0.390 \mathrm{~b}$ & $14.3 \mathrm{a}$ & 9.2 \\
\hline \multirow[t]{5}{*}{ gated } & 170 & $37.0 \mathrm{c}$ & $5.52 \mathrm{c}$ & $0.528 \mathrm{c}$ & $14.6 \mathrm{~b}$ & 9.6 \\
\hline & 240 & $34.3 \mathrm{bc}$ & $4.80 \mathrm{bc}$ & $0.476 \mathrm{~b}$ & $14.0 \mathrm{a}$ & 10.0 \\
\hline & $120+120$ & $32.2 \mathrm{bc}$ & $4.43 \mathrm{~b}$ & $0.416 \mathrm{~b}$ & $13.9 \mathrm{a}$ & 9.4 \\
\hline & $120+60+60$ & $31.0 \mathrm{bc}$ & $4.52 \mathrm{~b}$ & $0.406 \mathrm{~b}$ & $14.8 \mathrm{~b}$ & 9.0 \\
\hline & $\begin{array}{l}\text { Keskim. } \\
A v g .\end{array}$ & $30.6 \mathrm{~A}$ & $4.35 \mathrm{~A}$ & $0.407 \mathrm{~A}$ & $14.2 \mathrm{~A}$ & $9.4 \mathrm{~A}$ \\
\hline Sadetettu & 20 & $22.3 \mathrm{a}$ & $3.02 \mathrm{a}$ & $0.266 \mathrm{a}$ & $13.6 \mathrm{a}$ & 8.5 \\
\hline \multirow[t]{6}{*}{ Irrigated } & 120 & $33.1 \mathrm{~b}$ & $4.88 \mathrm{~b}$ & $0.381 \mathrm{~b}$ & $14.3 \mathrm{a}$ & 7.9 \\
\hline & 170 & $40.9 \mathrm{c}$ & $5.81 \mathrm{c}$ & $0.604 \mathrm{~d}$ & $14.3 \mathrm{a}$ & 10.4 \\
\hline & 240 & $41.3 \mathrm{c}$ & $5.89 \mathrm{c}$ & $0.503 \mathrm{c}$ & $14.4 \mathrm{a}$ & 8.5 \\
\hline & $120+120$ & $37.6 \mathrm{bc}$ & $5.46 \mathrm{bc}$ & $0.457 \mathrm{c}$ & $14.6 \mathrm{~b}$ & 8.4 \\
\hline & $120+60+60$ & $37.1 \mathrm{bc}$ & $5.43 \mathrm{bc}$ & $0.475 \mathrm{c}$ & $14.6 \mathrm{~b}$ & 8.8 \\
\hline & $\begin{array}{l}\text { Keskim. } \\
\text { Avg. }\end{array}$ & $35.4 \mathrm{~B}$ & $5.08 \mathrm{~B}$ & $0.447 \mathrm{~A}$ & $14.3 \mathrm{~A}$ & $8.8 \mathrm{~A}$ \\
\hline \multicolumn{7}{|c|}{ PME.0S (LSD) } \\
\hline Sadetus (Irriga & & 2.3 & 0.45 & NS & NS & 1.0 \\
\hline \multicolumn{7}{|c|}{ Sadetus $\times$ lannoitus } \\
\hline$($ Irrig $\times$ fertil. $)$ & & 6.0 & 0.94 & 0.087 & 0.95 & NS \\
\hline
\end{tabular}

\section{Tiivistelmä}

Typpilannoitusmäärän ja lannoitustapojen vaikutusta rehumaissin sadontuottoon ja raakavalkuaisen määrään tutkittiin vuosina 1976-1978 ja vastaavasti sadetuksen ja lannoituksen vaikutusta v. 1978 Suitian tilalla Siuntiossa. Koetekijöinä olivat rivija sijoituslannoitus sekä typpilannoitustasot. Sadetuskokeessa tutkittiin N-lannoitusmäärien ja -levitysaikojen vaikutusta satoihin.

Typpilannoitustavalla, rivi- tai sijoituslannoituksella, ei ole ollut merkittävää vaikutusta rehumaissin kuiva-ainesatoon, raakavalkuaissatoon ja raakavalkuaispitoisuuteen.

Typpilannoituksella $150 \mathrm{~N} \mathrm{kg/ha} \mathrm{kylvön} \mathrm{yhteydessä} \mathrm{annettuna} \mathrm{saatiin} \mathrm{suurim-}$ mat kuiva-ainesadot. Sitä suuremmat lannoitemäärät $2-3$ erässä levitettynä eivät ole lisänneet satotasoa.

Typpilannoitustason noustessa $100 \mathrm{~N} \mathrm{~kg}$ :sta/ha $250 \mathrm{~N} \mathrm{kg:aan/ha} \mathrm{lisääntyivät}$ sekä raakavalkuaispitoisuus että raakavalkuaissato merkittävästi. Sadetus lisäsi yhden kasvukauden tutkimuksissa rehumaissin satotasoa merkittävästi. Kokeessa käytetyt typpilannoitemäärät 120 ja $170 \mathrm{~N} \mathrm{~kg}$ /ha ovat antaneet sadettaen ja sadettamatta keskimäärin yhtä suuret sadot kuin $240 \mathrm{~N} \mathrm{~kg}$ /ha yhdessä tai useammassa erässä levitettynä.

Sadetuksella myös raakavalkuaissadot olivat suurempia, mutta raakavalkuais- $\%$ keskimäärin pienempi kuin sadettamatta. 


\section{Kirjallisuusluettelo}

ALLEN, M., ELLZEY, H. \& MONTGOMERY, C. 1974. Effect of nitrogen, population and hybrid on the yield and quality of irrigated corn to silage on Providena soil. Louisiana Agric. Exp. Sta. Bull. No 676.

ARNON, I. 1974. Mineral nutrition of Maize. Bern-Worblaufen, Switzerland: International Potash Institute.

BUNTING E. S. 1978. Agronomic and fysiological factors affecting forage maize production. (In Bunting et al. ed. forage maize ARC, London 1978.

CARR, M. \& HOUGH, M. 1978. The influence of climate on maize production in North Western Europe p. 15-56 Forage maize (ed. BUNTING et al). Agric. Res. Council. London 1978. 346 p.

CUMMINS, D. G. 1972. Yield and quality of corn for silage grown under different fertilizer regimes. Georgia. Agric. Exp. Stal. Bull. No 105.

DOSS, B., KING, A. \& PATTERSON, R. 1970. Yield Components and water use by silage corn with irrigation, plastic mulch, nitrogen fertilization and plant spacing. J. Agr. 62: 541: 544.

FLYNN, L. M., GEHRKE, C. W., MUHRER, M. E., SMITH, G. E. \& ZUBER., M. S. 1957. Effects of temperature, rainfall and fertilizer on composition of corn plants. Missouri Agr. Exp. Sta. Bull. 620.

HANWAY, J. J. 1962. Corn growth and composition in relation to soil fertility II. Uptake of N, P and their distribution in different plant parts during the growing season. Agronomy Journal 54: 217-222.

HEIL, M. 1975. Untersuchungen über des Einfluss von Sorte, Standort und Düngung auf einige technologische Qualitätseigenschaften des Maiskornes. Diss. Inst. Pfl.bau Pfl.züchtung Justus Liebing-Univ. 6 p. Giessen. 50-52. 176 p.

HØJMARK, V. 1977. Startg $\phi$ dning og stigende mangde kvaelstof ved dyrkning af majs til ensilering. Stat. Plantefors. Medd. 1336. 4 p.

KROTH, E. \& COLYER, D. 1967. Response of corn to nitrogen fertilization and plant population. Missouri Agric. Exp. Sta. Rep. 76.

LABER, B. 1976. Surwey of the use of maize for livestock feeding in Austria. Animal Feed Sci. and Tech. 1 (1976) 153-155.

LANZA, F. 1961. La concimazione minerale al mais con i fertilizzanti complessi Maydica, VI. 67-128.

LOUE, A. 1963. Maize nutrition. Cation and potash demand. World Crops, 15: 373-379.

PAIN, B. F. 1978. Nutritional requirements of forage maize. p. 87-116. Forage maize (ed. BUNTING et al.). Agric. Res. Council, London 1978. 346 p.

PEASLEC, D. \& MOSS, D. 1966. Photosynthesis in $\mathrm{K}$ and $\mathrm{Mg}$ deficient maize (Zea mays L.) leaves. Procedings of the soil Science Society of America 30: 220-223.

PULLI, S., TIGERSTEDT, P. M. A., KARA, O. \& BRÜNINGHAUS, G. 1979. Adaptation of silage maize varieties under extreme northern growing conditions in Finland. J. Scient. Agric. Soc. Finl. 51: 197209.

REINHARDT, H. 1971. Influence of soil and climate on yield reliability and yield level in maize. Bayerishches Lantwirtschaftliches Jahrbuch 48: 306-327.

WHITE, R. P. 1978. Cultural practices affecting maturity and yield of corn (Zea mays) for whole plant silage in short season areas. Can. J. Plant Sci. 58: 629-642.

VIRTANEN, A. I. 1940. Maissin viljelyksestä ensi kesänä. Karjatalous 8: Erip. 7 p. 